\title{
Aligning Paper Tests With Multimedia Instruction
}

Scott L. Howell

Brigham Young University, scott.howell@byu.edu

Follow this and additional works at: https://scholarsarchive.byu.edu/facpub

Part of the Educational Assessment, Evaluation, and Research Commons

\section{Original Publication Citation}

Howell, S. (2005). Aligning paper tests with multimedia instruction. In M. Achacoso \& M.

Svinicki, (Eds.),. Alternative strategies for evaluating student learning: New directions for teaching and learning: No. 100, (pp. 75-79). San Francisco: Jossey-Bass.

\section{BYU ScholarsArchive Citation}

Howell, Scott L., "Aligning Paper Tests With Multimedia Instruction" (2004). Faculty Publications. 2083. https://scholarsarchive.byu.edu/facpub/2083 


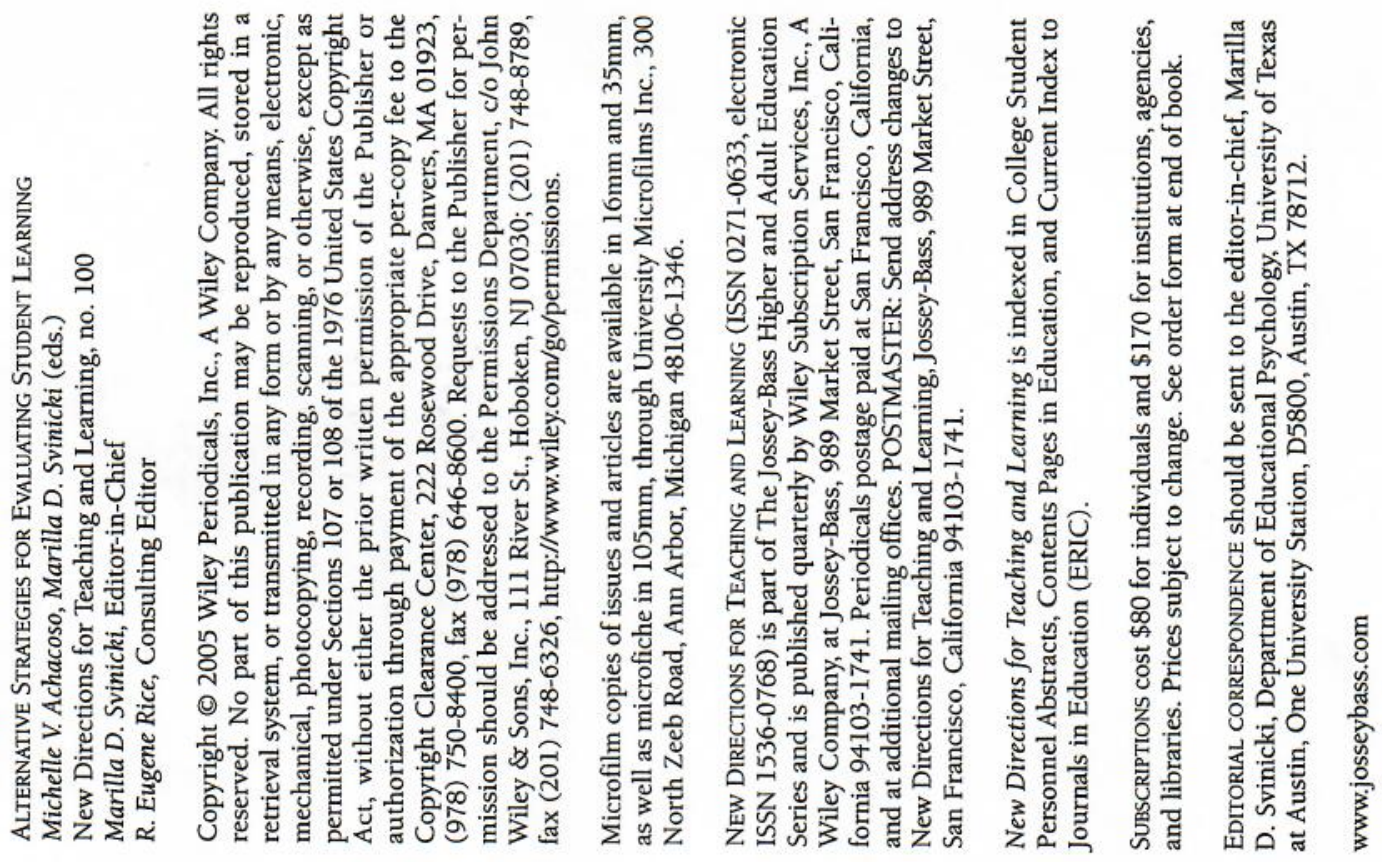

